\title{
Moneylenders and bankers: price-increasing subsidies in a monopolistically competitive market
}

\author{
Karla Hoff ${ }^{a, *}$, Joseph E. Stiglitz ${ }^{\text {b,1 }}$ \\ ${ }^{a}$ Economics Department, University of Maryland, College Park, MD 20742, USA \\ b Stanford University, Stanford, CA, 94305, USA and World Bank, Washington DC 20433, USA \\ Received 15 December 1997
}

\begin{abstract}
In many areas of the world, a significant part of the cost of obtaining a good or service is the cost of enforcing the contracts entailed in its provision. We present models of markets with endogenous enforcement costs, motivated by studies of rural credit markets. We show that subsidies may have perverse effects under monopolistic competition, increasing prices or inducing exit. Higher prices (interest rates) result from the loss of scale economies or from negative externalities among suppliers. The models are consistent with the puzzling evidence that infusions of government-subsidized formal credit have not improved the terms offered by moneylenders. (C) 1998 Elsevier Science B.V.
\end{abstract}

JEL classification: $016 ; 017 ; \mathrm{D} 43$

Keywords: Monopolistic competition; Enforcement; Reputation effects; Informal credit; Collectivist strategy

... [it is a] nearly universal fact that the poorest strata of the peasantry in many underdeveloped countries rely heavily, if not exclusively, on private moneylenders and not on sources of institutional finance. Indeed, financial

\footnotetext{
* Corresponding author. Tel.: (301) 405-3490; fax: (301) 405-3542; e-mail: hoff@econ.umd.edu.

1 This article replaces the first article which appeared in the Journal of Development Economics Vol. 52 (1997) 429-462.

${ }^{1}$ PII of original article: $503043878(96) 0043-9$
} 
institutions like banks and credit cooperatives typically do not consider them creditworthy, but paradoxically enough, private moneylenders do consider them creditworthy for advancing loans. (Bhaduri, 1987, p. 526)

Informal lenders are very thick on the ground. (Siamwalla et al., 1990, p. 277)

\section{Introduction}

Economists rarely discuss enforcement costs, and when they do, they usually focus on devices, such as reputation effects, that do not directly use up resources. ${ }^{1}$ Yet in many areas of the world, the governmental institutions for enforcing contracts are not well developed, and a significant part of the cost of obtaining a good or service is the direct cost of enforcing the contracts entailed in its provision. The purpose of this paper is to establish that with endogenous enforcement costs, a subsidy may raise the equilibrium price. The paper explores these issues in a context where enforcement problems are particularly acute and expenditures on enforcement are often large: rural credit markets in developing countries. ${ }^{2}$

The logic of the argument is as follows. A moneylender, once he has screened an individual and assessed the likelihood of repayment, is an imperfect substitute for any other moneylender. Therefore, if there is free entry into moneylending, the market is appropriately modelled as monopolistically competitive. If the marginal cost of moneylenders rises for some reason, then the equilibrium interest rate charged will increase. The paper will show how a subsidy, which lowers the private opportunity cost of funds to moneylenders, may cause the marginal cost of moneylending to rise. We will show this in a series of three models.

The first model is one with scale economies with respect to the variable transaction costs of lending. A subsidy induces new entry, and new entry reduces the market of each moneylender and forces him to operate at a higher marginal cost of transacting loans. This effect can raise the marginal cost of lending, so that equilibrium interest rates charged by moneylenders rise. ${ }^{3}$

\footnotetext{
${ }^{1}$ Such devices are not necessarily costless. Many enforcement mechanisms require rents. The rents themselves are transfers, but if the transfers are accomplished by raising prices above marginal costs, they create a distortion that has a resource cost associated with it. See, for example, Klein and Leffler (1981) and Shapiro and Stiglitz (1984). de Meza and Gould (1992) present an interesting model of endogenous, direct, private expenditures on enforcement in the context of a "commons" problem.

${ }^{2}$ See, in particular, Aleem (1990, Tables 5 and 6), who showed that in rural Pakistan transaction costs of moneylenders, including the costs of screening and enforcement, amounted to 39 percent of the amounts lent. This exceeded their capital costs - the cost of funds and bad debt - which amounted to 27 percent of the amounts lent.

${ }^{3}$ This result is related to two earlier papers. Horstmann and Markusen (1986) demonstrate the possibility that production subsidies have no effect on prices but only on entry in a Cournot model with free entry. de Meza et al. (1995) extend this result in a paper written independently of and concurrently with this paper. The set-up of the model here is quite different.
} 
The second model examines an alternative reason that subsidies may cause the marginal cost of moneylenders to rise. In this model, an increase in entry adversely affects borrowers' incentives to repay, which increases the enforcement effort that each moneylender must expend per borrower to ensure repayment. New entry thereby raises each moneylender's cost of taking on an additional customer. In the model, subsidies need not induce new entry, but if they do, interest rates may rise. The source of this perverse result is not scale economies, as in the first model, but enforcement externalities among moneylenders.

What is the source of enforcement externalities among moneylenders? With a larger number of informal lenders, borrowers may perceive that if they were to default and lose access to further credit from their current lender, it would be less difficult to find an alternative source of funds. The threat of cut-off from future loans thus has less value. In a study of a moneylender in Malawi, one of four full-time moneylenders in his area, it was observed that

Although ultimately bad debts are few - Mr. C. usually ends up getting what is due - collection is a major headache. Even so, many part-time moneylenders have entered the market ... Now that borrowers see other places to turn for funds, collection problems have worsened. (Bolnick, 1992, p. 61)

Moneylenders who are also traders and use the farmer's crop as collateral report in interviews that their ability to obtain repayment is reduced when, because of new entry, farmers' opportunities to make hidden "pirate" sales of their crop increases. Rice traders in Chile report that for this reason they cut back on the credit they used to advance to farmers (Conning, 1994, n. 17).

Others have observed that where the number of transactors in a credit market expands, the informal information-sharing networks on which moneylenders rely to learn a prospective borrower's credit history work less well. A view based on the anthropologist Polly Hill's work in Ghana is that

a marked decline in credit-guaranteeing by "landlords" in the Kumasi cattle market by the early 1960s was the result of a vast increase in the number of participants in the market, apparently more than could be monitored by the local information exchange. (Austin, 1993, p. 111)

The third model of this paper develops microfoundations for some of these observations. In this model, enforcement is ensured through a combination of collection effort by the moneylender and reputation effects that punish defaulters. Reputation effects are only as strong as the information flows that support them. In the model, the informal exchange of information about each borrower's credit history is less complete as the number of moneylenders increases, which weakens reputation effects. The weakening of reputation effects is a social cost of new entry into moneylending that takes the form of an increase in the equilibrium level of enforcement effort. As a result of the increase in enforcement costs, a subsidy that induces new entry may cause interest rates charged by moneylenders to rise. 
The questions these models raise are important because they relate to current public policy debates over subsidies to rural credit in developing countries. ${ }^{4}$ Whereas economists' intuition is that an increase in government-subsidized credit that benefits informal lenders must trickle down to the clients they serve, our analysis shows that with endogenous enforcement costs, that effect is likely to be attenuated and may even be reversed. Before presenting the models, we place them in the context of one type of rural credit market in which agricultural credit policy has played out.

\section{Framework of the models}

Many developing countries have pursued policies of cheap rural credit, which typically provide substantial amounts of credit at low interest rates to large landowners, who in turn often on-lend to small landowners: these generally are not deemed creditworthy by the formal sector. ${ }^{5}$ Conventional economic analysis suggests that a fall in the cost of funds to any group in a money market should lower the cost of credit to all through general equilibrium effects. Yet the consensus of those who have studied these markets is that in most rural areas where large inflows of subsidized, formal credit occurred, interest rates in the informal sector did not fall significantly, or at all, nor did the availability of informal credit increase. A well-studied example is Thailand. Despite the massive increase beginning in the late $1970 \mathrm{~s}$ in formal sector lending to rural areas in Thailand, interest rates that informal lenders charge have been stable (Siamwalla et al., 1990; Onchan, 1992 and citations therein). The regulated and subsidized formal credit sectors in Thailand, the Philippines, India, and Pakistan charge interest rates of 10-14 percent, whereas for those who give interest-bearing loans in the informal sector, the typical range of interest rates is 35-90 percent per year on loans for one cropping season. Interest-bearing informal sector loans, moreover, experience lower default rates than loans in the institutional, formal sector.

The models of this paper are motivated by recent studies of rural credit markets

\footnotetext{
${ }^{4}$ Related discussions are Floro and Ray (1997) and Bose (1994).

${ }^{5}$ For instance, Lipton and Toye (1989, pp. 183-184) examined projects involving rural credit in India and found that the majority excluded farmers with less than 2.5 or sometimes 5 acres. By this means several major World Bank-assisted credit projects excluded the smallest 50-75 percent of all operational holdings, although the credit was supposed to be for smallholders. Even when a class of small farmers is not barred from formal credit, the fixed costs of applying for it may be prohibitive (Sharma, 1985; Basu, 1994). Lipton (1976, p. 547) writes:
}

outside credit, especially if subsidized, drifts toward the big farmer, who is often a local moneylender; outside credit at $10 \%$, by covering production costs he would have incurred anyway, frees his cash and thus enables him to increase consumption-lending at $18-40 \%$. 
in developing countries, particularly those of Aleem (1990) for Pakistan, Bell (1990) for India, Siamwalla et al. (1990) for Thailand, and Floro and Yotopoulos (1991) and Nagarajan (1992) for the developed rural areas of the Philippines; an overview is in Hoff and Stiglitz (1993a,b). These studies suggest striking similarities in the behavior of informal lenders in areas where agriculture is commercialized. Typically, loans are an advance against the borrower's next harvest, and those in the best position to use that asset as collateral and to collect payment on debts are traders. ${ }^{6}$ This seems to explain why traders provide the lion's share of informal credit. ${ }^{7}$

Our models recognize four features characteristic of credit markets served by trader-lenders:

1. Scale economies. There are scale economies associated with the screening and enforcement activities undertaken by each moneylender. For instance, there may exist a minimum size warehouse to perform effectively the role of a trader-lender. Moreover, not all enforcement costs are fixed: scale economies appear to operate strongly at the level of the variable costs of screening and enforcement (see Aleem, 1990, Table 5).

2. Exclusivity. Each borrower is a customer of only one moneylender. ${ }^{8}$

3. Source of funds. Moneylenders lend primarily out of their own savings and out of government-subsidized funds (Bhaduri, 1987; Onchan, 1992, p. 106; Siamwalla et al., 1990, p. 289). Aleem found that

\footnotetext{
${ }^{6} \mathrm{~A}$ common pattern of enforcement is as follows:
}

The large moneylenders have regular employees who visit clients to learn the harvest date. The moneylender will then go to the threshing floor himself or send his employee with a bullock out to recover the principal and interest at the threshing floor (from a study of India (Walker and Ryan, 1990, p. 203)).

${ }^{7}$ According to a survey in Nueva Ecija, Philippines, lenders who are also traders provide 63 percent of the total value of informal credit to cultivators (including loans between friends and kin); authors' calculation from Nagarajan, 1992, Tables 4, 11, and 12. In the Punjab, India, credit interlinked with trade represents 62 percent of informal credit to cultivating households (Bell, 1990, Table 6). Data on northeastern Thailand, which do not distinguish between credit to non-cultivating versus cultivating households, show that trader-lenders provide 32 percent of total informal credit, and 72 percent of informal credit from lenders not resident in the borrower's village (Siamwalla et al., 1990, Table 4).

${ }^{8}$ Of the borrowers in the household survey in northeastern Thailand undertaken by Siamwalla et al. (1990, p. 279), five-sixths reported that they borrowed from only one informal source (Siamwalla et al., 1990, p. 279). Aleem (1990, p. 348) and Floro and Yotopoulos (1989, p. 78) note that a trader who lends money to a farmer generally requires him to market his crops exclusively through the trader; otherwise he is considered to be in default. This trade-credit linkage has been observed to be

[t]he most important enforcement mechanism used by a nonresident trader ... The insistence on this trade-credit linkage makes information on the size of the borrower's operations (and their changes) available to the creditor and to no one else. Trade-credit linkage thus closes the borrower's access to other lenders (Siamwalla et al., 1990, p. 282). 
on average approximately half of the funds used by the informal lender come from his own savings, 30 percent from institutional sources either directly or indirectly (from cotton mills, wholesalers, and so forth who have direct access to such funds), and the remainder from other informal lenders as well as from clients who use him as a safe deposit (at zero cost) for surplus cash. (p. 341)

The marginal cost of funds that moneylenders reported ranged from 20 to 50 percent (Aleem, 1990, Table 6), which reflected, in most cases, the cost of getting funds from other moneylenders.

4. Monopolistic competition. The market structure is monopolistically competitive. Although a borrower's relationship with a single informal lender typically extends over several years, new entry of moneylenders is observed (Aleem, 1990, p. 347), and borrowers do change moneylenders. Aleem (1990, p. 338) reported for Pakistan that

on average a borrower remains a repeat customer for approximately four periods, beyond which the farmer generally moved to another lender or left the market until he again needed to borrow funds.

Aleem undertook a direct test of the market structure of informal credit. In his detailed study of the operations of 14 informal lenders serving a rural area in Sind, Pakistan, he found that (i) on average, the marginal cost of lending as a fraction of the amount recovered was much less than the interest rate reported by borrowers, but (ii) total costs of lenders as a fraction of the amount recovered were comparable to the average interest rate. Competition drives profits down despite the market power of moneylenders.

Throughout the paper, our modelling framework has large landowners and small landowners. The large landowners are endowed with liquid capital $K$ and obtain a government-subsidized credit ration $G$ from a bank or other formal lending institution. The small landowners are deemed to offer insufficient collateral or to impose too high transaction costs to obtain credit from the formal sector. ${ }^{9}$ Large landowners are able to lend to small landowners if they pay a cost $\delta$, which gives them the capacity to screen borrowers and act as collection agents. We will call them moneylenders (although moneylending is not their only activity). Fig. 1 shows the flows of credit in the economy.

Our central results can be conveyed using the familiar diagram of Chamberlinian monopolistic competition in Fig. 2. For any given number of moneylenders,

\footnotetext{
${ }^{9}$ Our approach thus differs from Jain (1995), where neither enforcement problems nor transaction costs bar any set of borrowers from the formal sector. The empirical feature he focuses on is that small and medium-scale industry and trading firms in developing countries typically obtain substantial amounts of credit from both the formal sector (banks and other institutions) and informal lenders.
} 


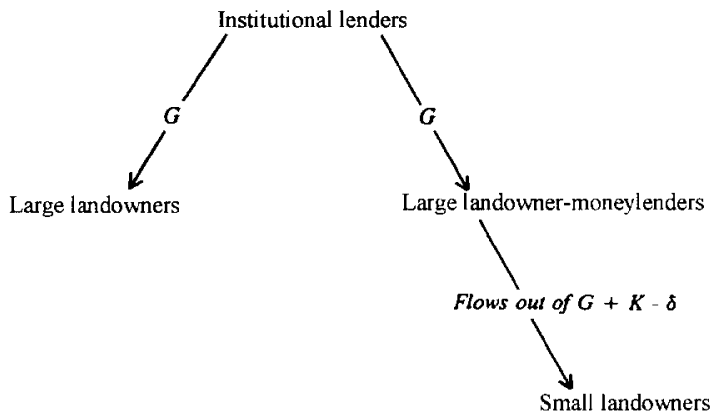

Fig. 1. Flows of credit

each perceives a downward sloping demand curve for credit, $L$, as a function of the interest rate, $i$. Let $1 / \epsilon$ denote the elasticity of the perceived inverse demand curve $(\epsilon \equiv-[\mathrm{d} L / \mathrm{d} i] i / L)$. The moneylender's average cost curve is U-shaped because of the fixed cost of being a moneylender and the increasing opportunity costs of capital diverted from his own land or other investment activities. An equilibrium point is characterized by two conditions: zero profits implying average cost (AC) per dollar lent equals the interest rate, and profit maximization implying

$$
\frac{\mathrm{dAC}}{\mathrm{d} L}=\frac{\mathrm{d} i}{\mathrm{~d} L}
$$

Together these two conditions imply that in equilibrium the elasticity of the average cost curve equals $-1 / \epsilon$. The initial equilibrium is depicted in Fig. 2 as point $E_{0}$, the tangency between the average cost curve and the demand curve. An expansion of subsidized credit from banks and other institutional lenders to large landowners reduces each moneylender's opportunity cost of capital and thus shifts his average cost curve down. The figure depicts the case where the subsidy

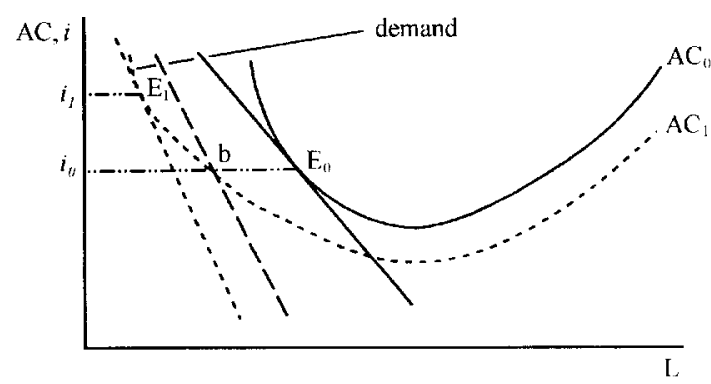

Fig. 2. A subsidy that increases price (i). 
induces new entry, which shifts inward the demand curve facing each moneylender. With either scale economies at the level of variable transaction costs (Model I) or enforcement externalities among moneylenders (Models II and III), we will show that the increase in the number of moneylenders may increase the marginal cost of lending. Now, a higher marginal cost reduces the slope of the average cost curve. If at the original interest rate, the elasticity of the average cost curve falls (in absolute value) relative to the value $1 / \epsilon$ of the new demand curve, then the new demand curve must cut the new average cost curve from above, as at point $b$; at that point, marginal cost exceeds marginal revenue and each moneylender has an incentive to raise his interest rate. The new equilibrium will be reached at a higher interest rate (as at $i_{1}$ ) after further entry occurs and each moneylender moves up his average cost curve. ${ }^{10}$

\section{Model I: scale economies}

This section presents a model where the moneylender has monopoly power over his share of the market. We show that if there are scale economies in the variable costs of lending, then an increase in subsidized formal credit may perversely raise the interest rate charged by moneylenders.

\subsection{Assumptions}

\subsubsection{Market structure}

There are a large number of potential borrowers, many of whom are not creditworthy. ${ }^{11}$ Before a moneylender screens a borrower, he cannot make a credible commitment with respect to the interest rate he will charge, and there is random matching between large landowners who have chosen to become moneylenders and individuals who seek a moneylender. (Model II relaxes these two assumptions.) Each moneylender screens his set of clients and learns who is creditworthy that period. There are enough idiosyncratic events that creditworthiness may change from period to period. At any one time, a farmer can be screened by only one moneylender. After the screening is done, the moneylender charges

\footnotetext{
${ }^{10}$ In Model II, the average cost curve of each moneylender depends on the total number of moneylenders. New entry shifts up the average cost curve and changes its elasticity. For clarity, Fig. 2 depicts only one shift in the average cost curve.

11 "Creditworthiness" simply refers to the likelihood that a loan will be repaid. Since enforcement is endogenous, in principle a borrower could be creditworthy with respect to one moneylender and not with respect to another. As described below, in this simplified model a borrower is either creditworthy in the informal sector (repays his loan) or not.
} 
the monopoly price to individuals found creditworthy, ${ }^{12,13}$ In the next period the process is repeated.

The model can be thought of as a three-stage game, where first large landowners decide whether to become moneylenders; then small landowners who are seeking credit are randomly distributed among moneylenders, who screen them; and then interest rates and loans get determined. Small landowners can switch after the initial pairing, but in equilibrium they will not wish to.

\subsubsection{Costs}

There is a cost $\delta(L)$ per period to obtain the capacity to screen borrowers and act as a collection agent, with $\delta(0)>0, \delta^{\prime}>0$, and $\delta^{\prime \prime}<0$. It is assumed that the fixed cost $\delta(0)$ is high enough that not all large landowners choose to be moneylenders. The assumption of a fixed cost can be given a simple interpretation. Where screening and enforcement are accomplished by serving as a small farmer's trader or miller, $\delta(0)$ includes the cost per period of a minimum size warehouse or mill.

The opportunity cost of funds is the moneylender's foregone output from his alternative investment opportunities, whose payoff is summarized by the function $F()$, with $F^{\prime}>0$ and $F^{\prime \prime}<0$.

\subsubsection{Demand}

There are a fixed number, $\bar{Z}$, of creditworthy borrowers in the informal sector in each period. The results of the analysis would be similar if $\bar{Z}$ were a function of the number of moneylenders, denoted $N$, but the calculations would be considerably more complex. ${ }^{14}$ Each of these $\bar{Z}$ borrowers has a demand for funds, $z(i)$, with $z^{\prime}<0$ and $z^{\prime \prime}$ less than an upper bound implicitly defined by the second-order condition in (3), below. For notational convenience, for the remainder of this paper, $i \equiv(1+$ the interest rate charged).

We will focus on the symmetric equilibrium, where each moneylender has $\bar{Z} / N$ borrowers. Define $\bar{Z} / N \equiv m$. A moneylender who charges $i$ thus lends $L=m z(i)$

\footnotetext{
${ }^{12}$ Aleem (1990, p. 335) found that on average the screening process by an informal lender takes one year (two seasons) during which the potential borrower, by marketing his output through the lender, demonstrates his productivity. On average, a lender then rejected more than half of the applicants screened.

${ }^{13}$ This corresponds to the general result that with strictly positive switching costs, sellers charge monopoly prices. This can be seen most easily in the case of the symmetric equilibrium. If all sellers charged a price slightly below the monopoly price, it would pay any seller to raise its price by an amount less than the switching cost. Each thus raises its price, until the monopoly price is attained. See Diamond (1971).

${ }^{14}$ Our results depend only on the property that when moneylenders attempt to recruit more "good" borrowers, they face increasing marginal costs. The consequence of this property is that a one percent increase in the number of moneylenders must induce a less than one percent increase in the total number of borrowers. New entry thus reduces the market of each moneylender.
} 


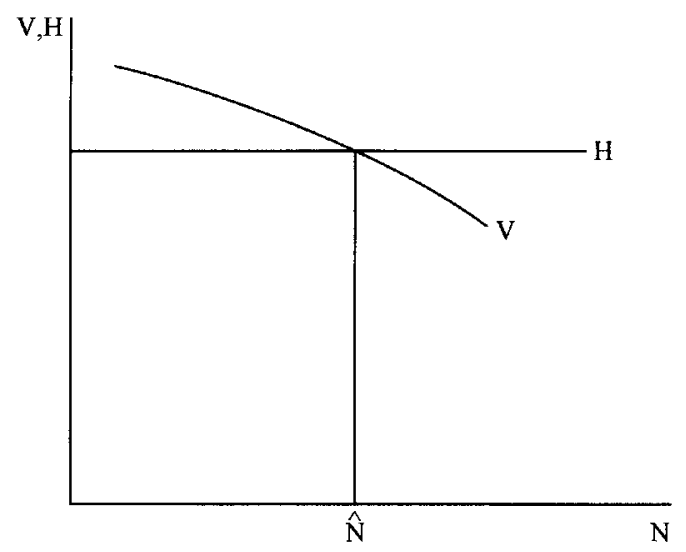

Fig. 3. At the equilibrium number of moneylenders, $\hat{N}$, the utility of a moneylender is the same as that of a large landowner who is not a moneylender.

\subsection{Market equilibrium}

Consider first the large landowner's decision to enter the moneylending activity. If he specializes in farming, his end-of-period income and utility are

$$
H(G) \equiv F(K+G)-r G
$$

where $r \equiv(1+$ the formal sector interest rate $)$. That is, a large landowner who borrows $G$ from a formal lender repays $r G$. If he enters the moneylending activity, his income and utility are

$$
V(N, G) \equiv \operatorname{Max}_{i}\{m i z+F(K+G-\delta-m z)\}-r G
$$

where miz is the principal and interest received from moneylending; and $\delta+m z$ is the amount spent on the moneylending activity, leaving $K+G-\delta-m z$ for alternative investments. Given $G$, the moneylending market is in equilibrium if the returns to moneylenders are equal to the returns to large landowners who are not moneylenders:

$$
V(N, G)=H(G)
$$

The equilibrium number of moneylenders can be read off Fig. 3 at point $\hat{N}$.

Before considering the slope of the $V$-curve, recall that the marginal cost of

\footnotetext{
${ }^{15}$ We employ the usual assumption that $N$ can be treated as a continuous variable without substantial error. That is, we ignore problems associated with the fact that $N$ must be an integer. (Formally, $N$ is the largest integer such that $V(N, G)>H(G)$.)
} 
lending an extra dollar is the opportunity cost of funds $\left(F^{\prime}\right)$ plus the marginal transaction cost $\left(F^{\prime} \delta^{\prime}\right)$. Let $c(L, G)$ denote their sum:

$$
c(L, G) \equiv F^{\prime}\left[1+\delta^{\prime}\right]
$$

and notice that $c_{L}=\delta^{\prime \prime} F^{\prime}-F^{\prime \prime}\left[1+\delta^{\prime}\right]^{2}$. This says that the marginal cost of lending, $c$, is decreasing (increasing) as the effect of scale economies in transaction costs is greater than (less than) the effect of the increasing opportunity cost of capital. $c_{L}<0$ implies that to operate on a larger scale in moneylending is to have a lower marginal cost of lending.

The curve of the moneylender's utility slopes down, as depicted in Fig. 3, since $V_{N}=-[m / N][i-c] z<0$. As the number of moneylenders increases, each moneylender loses $m / N$ customers in the new symmetric equilibrium, entailing a loss at a given interest rate of $[i-c] z$ per customer.

The moneylender's first-order condition is

$$
z^{\prime}[i-c]+z=0
$$

The moneylender sets his interest rate so that the foregone gain because each customer reduces his borrowing is just offset by the marginal increase in profits on the initial loan size. The second-order condition is

$$
\Delta \equiv 2 z^{\prime}+z^{\prime \prime}[i-c]-c_{L} m\left[z^{\prime}\right]^{2}<0
$$

This says nothing more than that "the moneylender's marginal revenue curve cuts the marginal cost curve from above." 16 The second-order condition rules out two potential problems: even if the marginal revenue curve is downward sloping, as expected, the marginal cost curve might be even more downward sloping because of scale economies; and the marginal revenue curve might not be downward sloping.

To summarize, (1) implicitly defines the equilibrium number of moneylenders as a function of $G$, and (2) implicitly defines the equilibrium interest rate they charge as a function of $N$ and $G: i=i(N(G), G)$. The model thus has a simple, separable structure: government subsidies affect entry into moneylending, and the two together determine $i$. The entire equilibrium can be depicted as in Fig. 4(A or B) for a given value of $G$, say $G_{0}$. The intersection at point $d^{\prime}$ of the solid curves representing $V\left(N, G_{0}\right)$ and $H\left(G_{0}\right)$ determines the number of moneylenders, and

\footnotetext{
${ }^{16}$ Proof: The marginal revenue curve MR (defined as the change in revenues as $L$ changes) cuts the marginal cost curve from above only if $\frac{\partial}{\partial z}(\mathrm{MR}-c)<0$ or, writing this in terms of the interest rate. $\frac{\partial}{\partial i}(\mathrm{MR}-c)>0$. Writing the latter inequality explicitly, we have$$
\frac{\partial}{\partial i}\left(i+\frac{z(i)}{z^{\prime}(i)}-c(L, G)\right)=2-\frac{z^{\prime \prime} z}{z^{\prime} z^{\prime}}-c_{L} m z^{\prime}>0
$$

Rearranging and using (2) yields (3).
} 

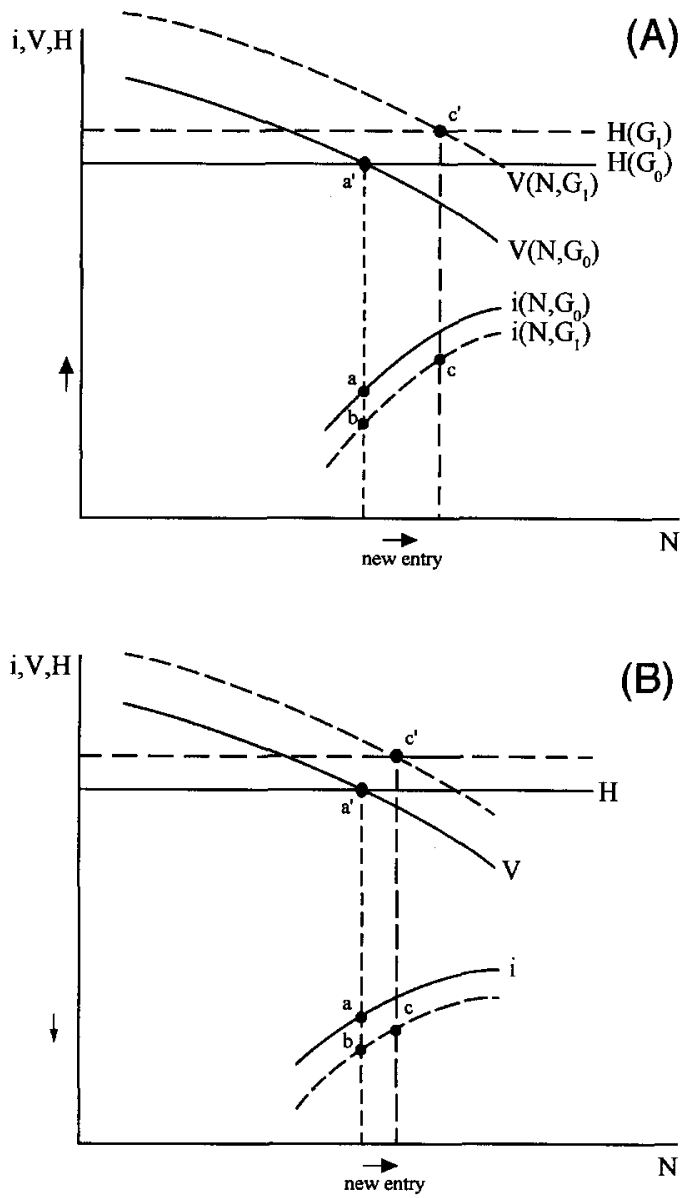

Fig. 4. This figure incorporates the effects of a change in $G$ on three different curves: $V, H$, and $i$. An increase in $G$ shifts the $i$ curve down and the $H$ and $V$ curves up, as shown in each panel. The short-run effect (from point $a$ to point $b$ ) is always to lower the informal interest rate. But the long-run effect on the interest rate (point $c$ ) is ambiguous. (A) Here, entry is induced and the movement along the $i(N, G)$ curve more than offsets the short-run fall in $i$. (B) Here, though entry is induced, the movement along the $i(N, G)$ curve is not sufficient to offset the short-run fall in $i$.

the equilibrium interest rate they charge can then be read off of the $i\left(N, G_{0}\right)$ curve at point $a$. The next paragraph analyzes the slope of the $i\left(N, G_{0}\right)$ curve.

Differentiating the first-order condition in (2) shows that the effect of new entry on each moneylender's interest rate is

$$
\frac{\partial i}{\partial N}=\frac{\frac{L}{N} c_{L} z^{\prime}}{-\Delta} \gtrless 0 \text { as } c_{L} \lessgtr 0
$$


New entry reduces each moneylender's market at a given interest rate by $L / N \Delta N$. According to whether marginal costs are decreasing (or increasing), operating on a smaller scale implies a higher (lower) marginal cost of lending, which raises (lowers) the interest rate that each moneylender will charge. The case $c_{L}<0$ in a neighborhood of the equilibrium is depicted in Fig. 4(A,B): in each figure the $i(N, G)$ curves thus slope up. (The case $c_{\mathrm{L}}>0$ is depicted in Fig. 7, discussed below.)

\subsection{Effect of an expansion in formal credit}

The initial impact of an expansion of government-subsidized credit, which can be seen by differentiating (2), is to lower the marginal cost of lending and so to lower $i$ :

$$
\frac{\partial i}{\partial G}=\frac{c_{G} z^{\prime}}{\Delta}<0
$$

This effect shifts down the $i(N, G)$ curve in Fig. $4(\mathrm{~A}, \mathrm{~B})$.

In the long-run equilibrium, there is also new entry. Differentiating the free entry condition in (1) with respect to $G$ shows that

$$
\begin{aligned}
& \frac{\mathrm{d}}{\mathrm{d} G}\{V-H\}=F^{\prime}(K+G-\delta-L)-F^{\prime}(K+G) \\
& =-F^{\prime \prime}(\bar{K})[\delta+L]>0
\end{aligned}
$$

where the first equation uses the envelope theorem and the second equation uses the mean value theorem (so $K+G-\delta-L<\bar{K}<K+G$ ). The inequality reflects the fact that at the margin moneylenders have better financial opportunities than non-moneylenders. ${ }^{17}$ These expanded opportunities to lend are what is

\footnotetext{
${ }^{17}$ The model assumes the absence of lending between large landowners. This is consistent with the observation reported in Section 2 that moneylenders lend primarily out of their own savings and out of government-subsidized funds. But our results do not depend on this assumption.

Consider, instead, the possibility that large landowners who are not moneylenders lend to those who are, so that capital flows from left to right in Fig. 1. Such lending would economize on fixed costs by permitting a moneylender to intermediate funds between many large landowners and many small landowners. But large landowners who lend to moneylenders also need to enforce the terms of such loans, and so it is plausible that they will require collateral. Now, collateral can be pledged only once. Assuming that there is a limit on the amount of collateral that a moneylender has, once that limit is reached, any increase in bank lending to large landowners (and thus any increase in the amount of their land that is mortgaged to banks), will crowd out intra-sectoral lending on a one-for-one basis. This strengthens our results. An increment in $G$ will be offset by a reduction in lending from large landowners to moneylenders, and the reduction in the lending of large landowners will, in turn, induce more large landowners to become moneylenders. Induced new entry will be larger in this case than occurred in the absence of this assumption. What drives the result that an increase in government-subsidized, formal sector lending induces new entry into moneylending is thus not the special assumption of no lending by large landowners to moneylenders, but only the condition that, at the margin, moneylenders have lending or investment opportunities that dominate those of non-moneylenders.
} 
"purchased" by the fixed investment in screening and enforcement capability, $\delta(0)$.

The greater is $\delta(L)+L$, the greater is the gap between the marginal productivity of funds to moneylenders and that to other large landowners, and thus the more that an increase in subsidized credit to large landowners differentially affects moneylenders and non-moneylenders. We will now show that the greater this gap, the greater the likelihood that in the presence of scale economies, an increase in subsidized formal credit to large landowners perversely raises the interest rate in the informal sector.

By differentiating (1) and simplifying using (2), we obtain the effect of $\Delta G$ on entry:

$$
\frac{\mathrm{d} \ln N}{\mathrm{~d} G}=F^{\prime \prime}(\bar{K}) \frac{[\delta+L]}{L} \frac{z^{\prime}}{z}>0
$$

The total effect of an increase in $G$ on a moneylender's interest rate is the direct effect plus the indirect effect via entry:

$$
\frac{\mathrm{d} i}{\mathrm{~d} G}=\frac{\partial i}{\partial G}+\frac{\partial i}{\partial N} \frac{\mathrm{d} N}{\mathrm{~d} G}=\frac{z^{\prime}}{\Delta}\left[c_{G}-c_{L} F^{\prime \prime}(\bar{K})[\delta+L] \frac{z^{\prime}}{z}\right]
$$

using (4), (5), and (6). The perverse result that informal lending falls, so $\mathrm{d} i / \mathrm{d} G>0$, is more likely to occur (i) the smaller is the direct effect on the marginal cost of capital, $c_{G}=F^{\prime \prime}\left[1+\delta^{\prime}\right]$; (ii) the more important are economies of scale (the larger is $-c_{L}$ ); and (iii) conditional on $c_{L}<0$, the larger is the gap between the marginal productivity of funds to moneylenders and to other large landowners $\left(F^{\prime \prime}(\bar{K})[\delta+L]\right),{ }^{18}$ and the larger is the elasticity of the demand for credit.

The upper part of Fig. 4(A) shows a case where the expansion of formal credit shifts the utility of the moneylender much more than that of the large landowner who is not a moneylender. The initial equilibrium is at points $a$ and $a^{\prime}$, and the short-run response to the expansion of formal credit reduces the informal sector interest rate as shown at point $b$. But the induced entry (shown by the arrow below the horizontal axis) is sufficiently large that the movement along the $i(N, G)$ curve offsets its downward shift, leading to an increase in the informal interest rate: the long-run equilibrium interest rate corresponding to point $c$ is above that corresponding to point $a$. In this case, the expansion of formal credit to large landowners decreases the aggregate supply of informal credit, as the reduction in each moneylender's lending more than offsets the increase in the number of moneylenders.

\footnotetext{
${ }^{18}$ But an increase in the fixed cost of entry, $\delta(0)$, has an ambiguous effect on the likelihood of the perverse outcome, $\mathrm{d} i / \mathrm{d} G<0$. It can be checked that, in addition to the direct effect on $\delta$ at any given $L$, an increase in $\delta(0)$, by raising the moneylender's opportunity cost of capital, can so decrease his lending that the sum $\delta(L)+L$ falls.
} 
Fig. 4(B) shows a case where the induced entry is smaller in relation to the downward shift in the $i(N, G)$ curve, so that the equilibrium interest rate falis. The interest rate at point $c$, the long-run equilibrium, is lower than the interest rate at point $a$, the initial equilibrium. Here the expansion of formal credit increases the aggregate supply of informal credit to the small landowners.

In both cases, the government subsidy is partly dissipated as a result of excessive entry into the moneylending activity.

\section{Model II: enforcement externalities and strategic interaction among mon- eylenders}

The idea of this section is that the enforcement effort by the moneylender to ensure repayment from any borrower depends on the costs the borrower bears if he defaults - costs that may diminish as the number of moneylenders increases, for the reasons discussed in the introduction. This externality-like effect on each moneylender's enforcement costs provides an alternative reason that a subsidy may perversely increase interest rates. One precise source of the externality based on the weakening of reputation effects - is established in Model III.

This section generalizes the competitive structure of the preceding model. The demand that each moneylender faces now depends on the interest rates charged by all other moneylenders. In this generalized model, because of the lower opportunity cost of funds, the initial impact of the expansion of formal credit is to lower the interest rate charged by each competitor. If the market structure is sufficiently competitive, this reduces the payoff to being a moneylender relative to the payoff to not being a moneylender, and so there is exit from moneylending. If there is exit, then subsidies are not dissipated. But the model shows that little of these savings may be passed through to borrowers in the informal sector because exit increases each moneylender's market power.

\subsection{Assumptions}

\subsubsection{Transaction costs}

A moneylender has a non-pecuniary cost of effort, denoted $e$, to ensure repayment from a borrower, with the properties

$$
e=e(N, z, i) \text { with } e_{N}>0, e_{z} \geq 0, e_{i} \geq 0, e_{z N} \geq 0, e_{i N} \geq 0
$$

It is reasonable to suppose that the cost of enforcement increases with the size of the loan and the interest rate charged. But what is important for our results is only the effect of the number of moneylenders on $e, e_{z}$, and $e_{i}$. (For implications of other properties of this function, see footnote 20.) The analysis is simplified, without affecting the qualitative results, by assuming that $e_{z z}=e_{i i}=e_{z i}=0$.

Section 5 derives a function $e(N, z, i)$ with the above properties as a reduced form of a model with reputation effects. In the model, an increase in entry reduces 
the probability that a default becomes known, which weakens reputation effects and hence the sanctions for default, and thereby increases the collection effort a moneylender must make to ensure repayment of a given debt.

Since this section aims to show that subsidies can increase interest rates even in the absence of decreasing marginal costs, set $\delta^{\prime}=\delta^{\prime \prime}=0$.

\subsubsection{Demand}

As before, there are $\bar{Z}$ borrowers with the ability to repay a loan, and each has a demand function $z(i)$. A strictly positive upper bound on $z^{\prime \prime}$ is implicitly defined by the second-order condition in (14) and the stability condition in (16).

\subsubsection{Market structure}

Moneylenders now make credible commitments with respect to the interest rates that they will charge before they screen a borrower. Suppose that a moneylender is in the market with $N-1$ other moneylenders, all offering a given interest rate $\bar{i}$. If the given moneylender raised his interest rate, we assume that his ability to recruit prospective borrowers would fall continuously and even differentiably. Likewise, if the rates of the other moneylenders increased, the given moneylender's ability to recruit prospective borrowers would increase. Finally, if all interest rates charged in the market were identical and fixed, while the number of moneylenders increased, then each moneylender's ability to recruit borrowers would again fall. As an idealization, we specify a function for the number of clients a moneylender obtains, $m=m(i, \bar{i}, N)$, where $\bar{i}$ is the interest rate charged by all others, and where $m()$ has the following properties ${ }^{19}$ :

Symmetry: $m(i, i, N)=\bar{Z} / N$ for all $i$

Imperfect substitutability across moneylenders:

$$
m_{i}<0, m_{i}>0, m_{i \bar{i}}>0, m_{i N}<0
$$

Stability condition: $m_{i i}+m_{i \bar{i}} \leq 0$

(9a) states that at any common interest rate $i$ charged by all moneylenders, each attracts the same number of clients. This implies that, starting from any common interest rate, if all moneylenders raise their interest rates by a given amount, then the market share of a given moneylender does not change. Differentiating ( $9 a$ ) by $i$ and $\bar{i}$ and setting $\mathrm{d} i=\mathrm{d} \bar{i}$, we have:

$$
m_{i}(i, i, N)+m_{i}(i, i, N)=0
$$

It also follows from symmetry that if the number of moneylenders increases,

\footnotetext{
${ }^{19} \mathrm{~m}()$ can be thought of as a specialization of a more general function that depends on the vector of interest rates charged by all large landowners, with the interest rates set at infinity in the case of large landowners who do not pay the fixed cost $\delta$ (since there is no interest rate at which, lacking the ability to enforce repayment, they would be willing to lend).
} 
then the market share of each falls by the same amount. Differentiating (9a) by $N$, we find $m_{N}(i, i, N)=-m / N$.

(9b) states that moneylenders are imperfect substitutes for each other. $m_{i \bar{i}}>0$ says that if other moneylenders raise their interest rates, then the number of customers a given moneylender loses by raising his own interest rate falls. The inequalities in (9b) imply that $i$ and $\bar{i}$ are strategic complements (see (15)) and that given any initial symmetric interest rate, an increase in the number of moneylenders increases the competitiveness of the market (see (18)).

(9c) is a technical condition that ensures that a stable price-setting equilibrium exists (see (16)).

\subsection{Market equilibrium}

For the moneylender, utility is now the sum of the financial return from lending to small landowners and from investing in non-moneylending activities, less the disutility of enforcement effort, $e$ per borrower. Define the moneylender's indirect utility function by a lower case $v$, where

$$
v(\bar{i}, N, G) \equiv \operatorname{Max}_{i}\{m[i z-e]+F(K+G-\delta-m z)\}-r G
$$

The first-order condition with respect to the interest rate is

$$
\psi(i, \bar{i}, N, G) \equiv m_{i}\left[z\left[i-F^{\prime}\right]-e\right]+m z^{\prime}\left[i-F^{\prime}-e_{-}\right]+m\left[z-e_{i}\right]=0
$$

The three terms of $\psi$ reflect, respectively, (i) the loss of customers, $m_{i}$, multiplied by the gain from lending to an extra customer, $z\left[i-F^{\prime}\right]-e$; (ii) the fall in each customer's loan size, $z^{\prime}$, multiplied by the gain from lending an extra dollar to every customer, $\left[i-F^{\prime}-e_{z}\right] m$, and (iii) the gain from charging a higher interest rate on the initial volume of loans, $m\left[z-e_{i}\right] .{ }^{20}$ It will be useful to rewrite (12) as

$$
z-e_{i}+z^{\prime}\left[i-F^{\prime}-e_{z}\right]=-\frac{m_{i}}{m}\left[z\left[i-F^{\prime}\right]-e\right]>0
$$

\footnotetext{
${ }^{20}$ We assume that $e_{i}$ is bounded above so that $\left[z-e_{i}\right]$ is positive in the relevant range. Under the alternative assumption, the lender's return $i z-e$ on a given loan size $(z)$ would not be everywhere monotone increasing in the interest rate, which, as in Stiglitz and Weiss (1981) or Williamson (1987). can generate equilibrium credit rationing. What is important to note here is that the lender's only motive for credit rationing in our model would be to reduce his enforcement costs. An increase in the number of moneylenders is a change in the environment that raises the costs per borrower of enforcement. For $e_{i N}>>0$, new entry would switch the equilibrium from a market-clearing equilibrium to a rationing equilibrium; within a rationing regime, new entry would increase the extent of rationing. The possibility of credit rationing in these ways strengthens the argument of this paper that a subsidy that increases entry may reduce aggregate informal lending.
} 


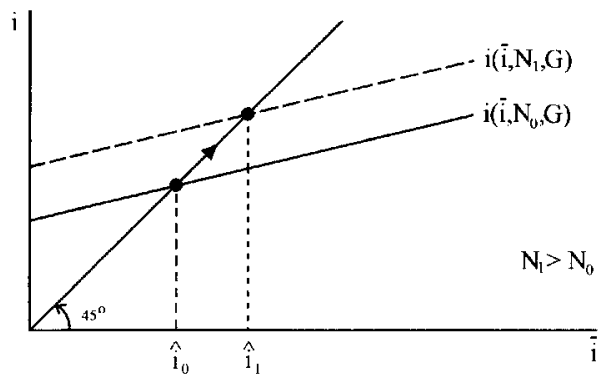

Fig. 5. An increase in $\mathrm{N}$ may lead to an increase in $i$ at a fixed value of $\bar{i}$. Feedback reactions lead to a further increase in the equilibrium rate of interest.

which says that the moneylender equates the gain per customer from a marginal increase in $i$ to the loss from the induced departure of customers.

As in Model $\mathrm{I}$, the economic content of the second-order condition is that the slope of the marginal revenue curve must be less than the slope of the marginal cost curve (which is now $-F^{\prime \prime}>0$ ). The second-order condition is

$$
\begin{aligned}
\psi_{i}= & 2 m_{i}\left[z-e_{i}+z^{\prime}\left[i-F^{\prime}-e_{z}\right]\right]+2 z^{\prime} m+m_{i i}\left[z\left[i-F^{\prime}\right]-e\right] \\
& +F^{\prime \prime}\left[m_{i} z+m z^{\prime}\right]^{2}+m z^{\prime \prime}\left[i-F^{\prime}-e_{z}\right]<0
\end{aligned}
$$

Noting (13), all terms on the right-hand side of (14) are negative except the last, which is ambiguous in sign. As in the previous model, the second-order condition implicitly imposes an upper bound on $z$ ": demand cannot be "too convex."

The interest rate chosen by a given moneylender now depends on that chosen by others. Differentiating (12) shows that $\partial i / \partial \bar{i}=-\psi_{i} / \psi_{i}$ where

$$
\psi_{\bar{i}}=-\epsilon_{\bar{i}} \frac{m}{i} z\left[i-F^{\prime}-e\right]+F^{\prime \prime} m_{\bar{i}} z\left[m_{i} z+m z^{\prime}\right]>0
$$

(using (13)). $i$ increases with $\bar{i}$ (that is, they are strategic complements) because an increase in $\bar{i}$ increases the moneylender's market power ${ }^{21}$ and because, by increasing his market share, it raises his marginal opportunity cost of funds (at any given $i$ ).

Fig. 5 depicts the reaction function. For given $N$ and $G$, the symmetric equilibrium in interest rates is the intersection of the reaction function with the $45^{\circ}$

\footnotetext{
${ }^{21}$ That is, it decreases the elasticity of his perceived demand curve for loans, $\epsilon=-\mathrm{d} \ln (m z) / \mathrm{d} \ln (i)$. Using (9b), we find$$
\epsilon_{\bar{i}}=\frac{i}{m}\left[\frac{m_{\bar{i}} m_{i}}{m}-m_{i \bar{i}}\right]<0
$$ 
line. The symmetric equilibrium is stable provided that the slope of the reaction function is less than one; that is, provided that

$$
-\psi_{i}>\psi_{i}
$$

(16) says that the effect on the moneylender's marginal returns $\psi$ from a change in his own interest rate is larger than the effect from a change in the interest rate charged by other moneylenders. ${ }^{22}$

Now consider how the reaction function shifts with new entry (an increase in $N)$. Starting from any common interest rate charged by all moneylenders, and differentiating $\psi$ with respect to $N$, we find $\partial i / \partial N=\psi_{N} /\left[-\psi_{i}\right]$, where

$$
\begin{aligned}
\psi_{N}= & -\epsilon_{N} \frac{m}{i}\left[z\left[i-F^{\prime}\right]-e\right]-m_{i} e_{N}-m\left[e_{z N} z^{\prime}+e_{i N}\right] \\
& -F^{\prime \prime} \frac{L}{N}\left[m_{i} z+m z^{\prime}\right]
\end{aligned}
$$

using (13). Whether $\psi_{N}$ and, hence, $\partial i / \partial N$ is positive or negative depends on three factors:

1. A monopoly power effect, represented by the first term on the right-hand side of (17). New entry reduces each moneylender's market power since

$$
\epsilon_{N}=-\frac{i}{m}\left[\frac{m_{i}}{N}+m_{i N}\right]>0
$$

This effect tends to lower $i$ by a greater amount, the greater the moneylender's profits on the marginal loan, $z\left[i-F^{\prime}\right]-e$.

2. An enforcement cost effect, represented by the second and third terms on the right-hand side of (17). New entry increases each moneylender's enforcement costs per borrower (since $e_{N}>0$ ), which lowers the gain from winning a new customer and so raises $i$. This effect is larger, the more competitive the market (the greater is $-m_{i}$ ). The term $e_{z N} \geq 0$ captures the effect of new entry on the marginal cost of lending an extra dollar, thus also raising $i$. On the other hand, new entry changes by $e_{i N} \geq 0$ the increment to enforcement costs induced by a marginal increase in $i$, which tends to lower $i$.

3. A cost of capital effect, represented by the last term of (17). With new entry, each moneylender's lending at any given interest rate falls at the rate $L / N$, which reduces his opportunity cost of capital by $F^{\prime \prime} L / N$, and so tends to lower $i$.

If in (17) the enforcement cost effect is positive and exceeds the sum of the monopoly power and cost of capital effects, then the perverse result occurs where

\footnotetext{
${ }^{22}$ It can be checked, using $(9 \mathrm{~b}, \mathrm{c})$ and $(10)$, that a sufficient condition for (16) is that the borrower's demand curve $z(i)$ not be too convex. We will assume that this condition is satisfied.
} 
an increase in the number of moneylenders increases the interest rate: $\partial i / \partial N>0$. One explanation for the enforcement cost effect, which we will model explicitly in Section 5 , is that the informal exchange of information about each borrower's credit history becomes less complete as the number of moneylenders increases and, as a result, reputation effects weaken. As reputation effects weaken, the effort a moneylender must make to enforce the terms of a loan increases, which raises his marginal cost of lending. ${ }^{23}$ This is consistent with observations of actual informal lenders discussed in the introduction. This case is depicted by the dashed line in Fig. 5. New entry shifts up the reaction curve, which leads to a larger increase in the equilibrium interest rate, denoted by $\hat{i}(=i=\bar{i})$, because of the positive feedback.

It remains to consider the decision by large landowners to enter the moneylending activity. Let an upper case $V$ denote a moneylender's indirect utility function in a symmetric equilibrium:

$$
V(N, G) \equiv v(\hat{i}(N, G), N, G)
$$

Given $G$, the moneylending market is in equilibrium if the returns to moneylenders are equal to the returns to large landowners who are not moneylenders:

$$
V(N, G)=H(G)
$$

Assume that a stable equilibrium exists. To see the condition that guarantees stability, consider how the moneylender's utility changes with $N$. As $N$ increases for given interest rates, each moneylender's utility $v(\hat{i}, N, G)$ changes by

$$
v_{N}=-\frac{m}{N}\left[z\left[i-F^{\prime}\right]-e\right]-m e_{N}<0
$$

His market share falls and his enforcement costs rise, and both effects reduce his utility. But because of strategic interaction among moneylenders, new entry has a third, indirect effect on his utility. If $\psi_{N}>(<) 0$, then as $N$ increases, each competitor raises (lowers) his interest rate, which makes the moneylender better off (worse off) since he gains from a higher interest rate charged by his competitors:

$$
v_{\bar{i}}=m_{\bar{i}}\left[z\left[i-F^{\prime}\right]-e\right]>0
$$

\footnotetext{
${ }^{23}$ A model with an interesting relation to this paper is Satterthwaite's (Satterthwaite, 1979) analysis of reputation goods (e.g., medical services). In his model, an increase in entry reduces the information that consumers have about alternative sources of supply, in turn reducing their willingness to switch suppliers and so increasing each supplier's market power. In his model, the weakening of reputation effects lowers the elasticity of demand. In our model, it lowers the elasticity of the average cost curve. In both cases, an increase in the number of suppliers may lead to an increase in price.
} 


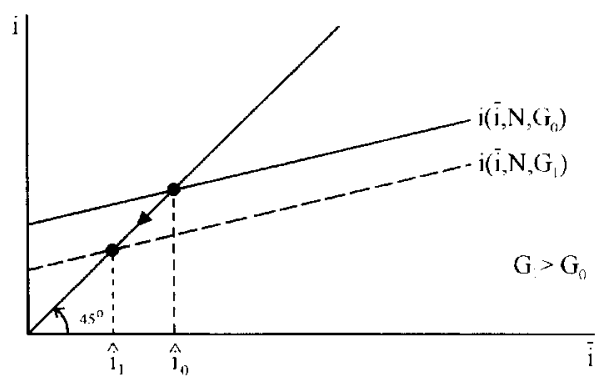

Fig. 6. An increase in $\mathrm{G}$ at a fixed $N$ and $\bar{i}$ results in a lower interest rate, as the supply of funds increases. With endogenous $\bar{i}$ the equilibrium interest rate is reduced even more, as a result of feedback effects.

Stability requires that the total derivative of $V$ with respect to $N$ be negative in a neighborhood of the stable equilibrium, $\hat{N}:{ }^{24}$

$$
V_{N}(\hat{N}, G)=v_{N}+v_{i} \frac{\mathrm{d} \hat{\imath}}{\mathrm{d} N}<0
$$

\subsection{Effect of an expansion of formal credit}

The case of no strategic interaction modelled in Section 3 had a convenient separable structure. In doing comparative statics, we could solve first for the change in $N$, and then use that result in deriving the change in $i$. With strategic interaction, the model is no longer separable. Here we present our results diagrammatically, leaving the proofs to Appendix A.

As before, an increase in subsidized formal credit to large landowners lowers $i$ (and thus increases informal lending) for any given $\bar{i}$ and $N$. The dashed line in Fig. 6 depicts the shift in the reaction function due to an increase in $G$. The shift leads to a larger drop in the value of $\hat{i}$ because of the negative feedback. Thus, the curve describing the interest rate as a function of $N$ shifts down, just as depicted in the lower part of Fig. 4(A,B). These two figures illustrate two possible outcomes in Model II, except that now the rising slope of the interest rate curve reflects the effect of new entry on enforcement costs, not the loss of (within-firm) economies of scale (see Proposition 1 below).

\footnotetext{
${ }^{24}$ We know that $V(N, G)$ is bounded by the cooperative solution, say $V^{+}$, and that $V^{+}$declines with $N$. That is,

$V^{+}(N, G)$

$\equiv \max _{i^{+}}\left\{m\left(i^{+}, i^{+}, N\right)\left[z\left(i^{+}\right) i^{+}-e\left(z\left(i^{+}\right), i^{+}, N\right)\right]+F\left(K+G-\delta-m\left(i^{+}, i^{+}, N\right) z\left(i^{+}\right)\right)\right\}-r G$

and from (20) and the envelope theorem, $V_{N}^{+}<0$. The fact that $V(N, G)$ may not be monotonic in $N$ implies that there may be multiple equilibria.
} 


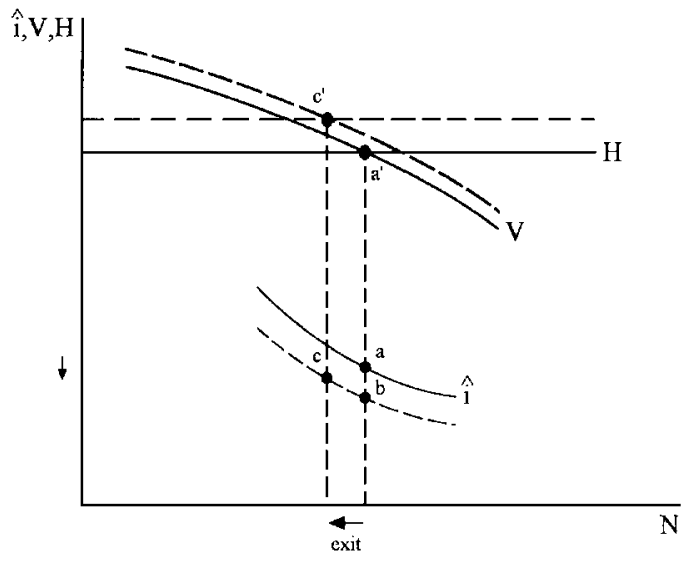

Fig. 7. With strategic interaction among moneylenders, an increase in $\mathrm{G}$ may lead to exit from the moneylending business. As in Panel 4B, the short-run fall in the interest rate from point $a$ to point $b$, in response to an increase in $\mathrm{G}$, is partially offset by the long-run adjustment from point $b$ to point $c$.

Fig. 7 illustrates a new possibility. The two lower curves of Fig. 7 illustrate a case which, in partial equilibrium terms, many might think to be more "normal": the cost of capital and monopoly power effects of an increase in $N$ dominate the enforcement cost effect, so that $\hat{i}$ is a decreasing function of $N$. The upper part of Fig. 7 illustrates the case where an increase in $G$ so reduces interest rates among a given set of moneylenders, which so reduces each moneylender's profits, that the moneylender's utility decreases relative to that of a large landowner who is not a moneylender: $\partial\{V-H\} / \partial G<0$, and there is exit from the moneylending activity (see Proposition 2 below). Just as before, an expansion of formal credit lowers the $\hat{i}$ curve at each $N$; at a given $N$, the interest rate moves from point $a$ to point $b$ in Fig. 7. But long-run adjustments will partially, though not completely, reverse this short-run effect. The fall in the profitability of lending induces exit, and the exit of moneylenders increases the monopoly power of those large landowners who remain moneylenders. The movement along the $\hat{i}$ curve from point $b$ to point $c$ for this reason offsets its downward shift, but now the offset is only partial: point $c$ must correspond to an interest rate at least slightly below the initial interest rate at point $a$ (Proposition 3 below).

The intuition behind Proposition 3 is straightforward. Exit occurs if, and only if, at the initial number of informal lenders, moneylending has become unprofitable, which (given that $G$ has risen) can occur only if the informal sector interest rate falls.

From an efficiency perspective, Fig. 7 depicts a much more desirable case than Fig. 4A. Fewer resources are dissipated in fixed costs of enforcement, $\delta(0)$, and in enforcement effort. But little of these savings may be passed onto borrowers. As 
exit occurs from moneylending, the market power of each moneylender increases, which is reflected in the upward movement in interest rates along the $\hat{i}\left(N, G_{1}\right)$ curve. The long-run upward movement partially offsets the short-run decline. In terms of the criterion of benefitting the small landowner through lower interest rates, the two cases differ little.

Appendix A proves three propositions:

PROPOSITION 1. If the enforcement cost effect is positive and sufficiently large relative to the effect that new entry has on the moneylender's opportunity cost of capital and on his market power, then the informal sector interest rate will rise as formal credit increases.

PROPOSITION 2. If there is no strategic interaction among moneylenders ( $m_{\bar{i}}=$ 0 ), then an increase in formal credit will induce new entry into moneylending. If strategic interaction is important $\left(m_{i}\right.$ is large), an increase in formal credit may induce exit from the moneylending activity.

PROPOSITION 3. If the increase in formal credit induces exit, then the informal sector interest rate must fall.

\section{Model III: enforcement costs and reputation}

This section develops a reputation model from which equation (8) is derived as a reduced form. We can get that result even in the simple case of homogeneous borrowers.

In the model, default is prevented by a combination of reputation effects and the moneylender's enforcement effort. Reputation effects require fast and accurate information flows. The importance of informal information transmission suggests that the more moneylenders there are, the lower the probability that the required information will be transmitted quickly to each, and therefore the weaker reputation effects will be. The question that our model investigates is how that change in information affects the level of enforcement effort that each moneylender must apply to ensure repayment.

To investigate the question requires a model where a default in one period may trigger a punishment in the future: that is, we require that for each borrower, there always be a "next period" with strictly positive probability. To capture this idea, we now assume that borrowers live an infinite number of periods and have a time discount factor $\beta \in(0,1) .{ }^{25}$

\footnotetext{
${ }^{25}$ As is well known, models with finite-lived agents where the date of the terminal period is uncertain have properties similar to those with infinite-lived agents.
} 
Enforcement effort takes the form of visiting the borrower's farm around the time of the expected harvest. The level of enforcement effort might be thought of as the number of days before the expected optimal harvest date that the moneylender begins to visit the borrower's farm. A borrower chooses whether to default or repay. If he repays, his payoff in that period is $u^{r}(z, i)>0$. If he defaults, his payoff in that period depends on (a) the size of his debt and (b) the level of the moneylender's enforcement effort. The idea behind (b) is that the higher the moneylender's enforcement effort, the greater the borrower's own effort must be to evade him (or the earlier the borrower needs to harvest his crop, with consequent loss in value, in the situation where enforcement effort is associated with the number of days before the optimal harvest date that the moneylender begins to visit the borrower's farm ${ }^{26}$ ). For simplicity, we write the borrower's payoff in that period if he defaults as a separable function that is linear in the moneylender's enforcement effort, $e: U(z, i, e) \equiv u^{d}(z, i)-e$. We make the natural assumption that $u^{d} \in\left(u^{r}, \infty\right)$ and

$$
\frac{\partial}{\partial z}\left\{u^{d}-u^{r}\right\} \geq 0, \frac{\partial}{\partial i}\left\{u^{d}-u^{r}\right\} \geq 0
$$

(23) says that the borrower's incentive to default on a loan increases with its size and interest charge.

Notice that $e$ is always a cost to the moneylender, whereas it is a cost to the borrower only if he defaults. We are interested in the general class of cases where (a) moneylending in the absence of enforcement costs $e$ is profitable, that is, where

$$
m z(i) i+F(K+G-\delta-m z(i))>F(K+G) \text { for some } i
$$

from which it follows immediately that

$$
z\left[i-F^{\prime}\right]>0
$$

and where, at the same time, (b) the moneylender's own enforcement effort cannot sustain lending in a one-shot game, that is,

$$
e \geq u^{d}-u^{r} \Rightarrow z\left[i-F^{\prime}\right]-e \leq 0 \text { for all } i
$$

(24b) says that the effort needed to ensure repayment in a one-shot game more than exhausts the moneylender's financial gain from lending. Hence, lending is

\footnotetext{
${ }^{26}$ Support for this interpretation is provided by the following report:

One type of farmer who finds it difficult to borrow from non-resident traders is the cassavagrowers, for the simple reason that cassava, unlike other crops, can be harvested at any time between four and fourteen months after planting. Without a fixed harvest period, the enforcement problem becomes very difficult. (Siamwalla et al., 1990, p. 282).
}

For cassava, early harvesting to evade the moneylender could thus be costless to the farmer. Without a means to raise the costs of evasion, the moneylender refuses to lend. 
unprofitable unless the moneylender can rely at least in part on the future penalties the borrower suffers from default.

At the end of each period, the moneylender decides whether or not to terminate his relationship with the borrower. He terminates the relationship if the borrower defaults. If the borrower repays, the moneylender continues the relationship if he remains in the market. To capture the idea that moneylenders have limited ability to commit to future lending, we assume that there is an exogenous probability $b$ that a moneylender leaves the market at the end of any period.

An individual who is not attached to a moneylender must go through another one-period screening process with a moneylender. As in Models I and II, at any one time a borrower can be screened by only one moneylender. In that period he obtains no credit and zero utility.

If a borrower has defaulted, and it is known that he has defaulted, then moneylenders will not lend to him, for reasons that we will see shortly (Proposition 5 , below).

Let $\pi$ denote the probability that a bad credit history is "forgotten" in the sense that an individual who has defaulted in the past passes a moneylender's screening test (thereby obtaining credit). For given $\pi$, the next proposition specifies the lowest enforcement effort $e^{*}$ that induces repayment by a borrower with no history of default.

PROPOSITION 4. The best response of a borrower who has repaid in the past is to repay in the future provided that the moneylender's enforcement effort satisfies

$$
e \geq u^{d}-u^{r}-\beta u^{r}\left\{\frac{1-b+\beta[b-\gamma]}{1-\beta[1-b+b \beta]}\right\} \equiv e^{*}
$$

where

$$
\gamma \equiv \frac{\pi}{1-\beta[1-\pi]}
$$

Proof. The present value of lifetime expected utility of a borrower who always repays and who is currently attached to a moneylender is denoted by $W^{r}$ :

$$
W^{r} \equiv u^{r}+\beta[1-b] W^{r}+\beta^{2} b W^{r}
$$

The present value of lifetime expected utility of an individual who has defaulted in the past, who currently is being screened by a moneylender, but who will repay any debts he obtains in the future, is

$$
W^{d} \equiv \beta \pi W^{r}+\beta[1-\pi] W^{d}
$$


To show that an individual's best response is always to repay, it is sufficient to show that

$$
W^{r} \geq u^{d}-e+\beta W^{d}
$$

Substituting and rearranging yields (25).

The borrower's incentive to repay a given loan depends on the one-period gain from default $\left(u^{d}-u^{r}-e\right)$, and the difference between his future utility streams if he does or does not default. Default will be prevented only if the present discounted value of this difference between future utility streams exceeds the one-time gain the borrower obtains from default. Anything that increases this difference reduces $e^{*}$. Hence, $e^{*}$ is decreasing in the utility index $u^{r}$, the probability $1-b$ of continuing the relationship with the current moneylender if the borrower repays, and the discount factor $\beta$. It is increasing in the probability $\pi$ of finding another moneylender if the borrower defaults.

It remains to verify that in the neighborhood of perfect information $(\pi=0)$, and any given values of $u^{d}, u^{r}$, and $b$ such that $u^{d}>u^{r}>0$ and $0 \leq b \leq 1$, there exists a set of values of $\beta$ for which $e^{*}$ is strictly positive and moneylending to individuals with a good credit history is profitable. $e^{*}$ is a continuous, strictly monotonically decreasing function of $\beta$. As $\beta \rightarrow 1$, we have $e^{*} \rightarrow-\infty$. As $\beta \rightarrow 0, e^{*}$ is strictly positive. This implies that there exists a unique $\bar{\beta}$ such that for $\beta=\bar{\beta}, e^{*}=0$ : borrowers repay irrespective of the moneylender's enforcement effort since the value of a good reputation as compared to the one-time gain from default becomes arbitrarily large as $\beta$ approaches 1 . For $\beta<\bar{\beta}, e^{*}>0$. Whether lending is profitable depends on $e^{*}$. At $\beta=\bar{\beta}$, lending is strictly profitable (by the assumption made in (24a)); hence, for $\beta$ near $\bar{\beta}$, it is also strictly profitable. As $\beta$ decreases below $\bar{\beta}$, the profitability of lending decreases. In the limit as $\beta \rightarrow 0$, lending is unprofitable (by the fact that $\lim _{\beta \rightarrow 0} e^{*}=u^{d}-u^{r}$ and the assumption made in (24b)). Hence, there exists a unique $\beta$ such that if and only if $\beta \geq \beta$ does the moneylender wish to lend to individuals with a good credit history.

In summary, we have shown that there exists a unique subset of $(0,1)$, denoted $(\beta, \bar{\beta})$, such that for $\beta \in(\beta, \bar{\beta})$, the moneylender wishes to lend to individuals with a good credit history and $e^{*}$ is strictly positive. We will assume that $\beta \in(\underline{\beta}, \bar{\beta})$. Note that $\underline{\beta}$ is a function of $b$, with $\underline{\beta}^{\prime}(b)>0$. This reflects the fact that an increase in the exogenous probability of separation from his moneylender lowers a borrower's payoff from repaying a loan, while an increase in the discount factor raises it.

Will moneylenders who operate independently of each other turn away prospective borrowers with a bad credit history? A necessary condition is that those who do so expect to gain, and those who do not do so expect to lose. These expectations depend on the beliefs that each moneylender has about other moneylenders' strategies. By analogy with Greif's (Greif, 1994) model of merchantagent relations, define a collectivist strategy as one where a moneylender does not 
lend to individuals who he knows have defaulted in the past. The next proposition provides sufficient conditions for the collectivist strategy to be an equilibrium.

PROPOSITION 5. If $\beta>\beta(b)$ when $b=1$, then there exists a value $b \in(0,1)$ such that for $b>b$, the collectivist strategy combination under complete information is a subgame perfect equilibrium.

The proof, which is in Appendix B, depends on the assumption in (24b) that to induce repayment it is not profitable for the moneylender to rely solely on his current enforcement effort. If lending is to be profitable, the threat to the borrower of a loss of future income is also necessary to induce repayment. Part of this threat comes from the fact that if a borrower defaults, his moneylender cuts off access to future credit. But for $b$ high enough, that threat is not enough; the loss of one's reputation with other moneylenders is also necessary to induce repayment. This means that for $b$ high enough, no moneylender can profitably lend (at any interest rate) to an individual who has already lost his reputation: expectations that moneylenders will refuse to lend to those with a bad credit history are self-fulfilling. 27

We evaluated the collectivist strategy combination above at $\pi=0$, i.e., rapid transmission of perfect information. In reality, there are no credit bureaus in the rural sector of developing countries to ensure perfect information. ${ }^{28}$ Moneylenders rely instead on informal information-sharing networks. With a small number of moneylenders, this may work well. But as the number of moneylenders increases, it is plausible that the probability that an individual's credit history is known decreases, as suggested in the introduction. Formally, this idea is captured by specifying that $\pi$ is a function of $N, \pi^{\prime}(N) \geq 0$, with strict inequality for $N$ sufficiently large.

Proposition 6 relates the equilibrium level of enforcement effort to the number of moneylenders and to the terms of the current loan offered by a given moneylender, denoted by $\left(z_{0}, i_{0}\right)$. It can be proved by substituting the function $\pi(N)$ for the parameter $\pi$ in (25), and using (23).

PROPOSITION 6. If the collectivist strategy combination is an equilibrium, and if the probability that a moneylender has information on the past history of default of an individual is a strictly decreasing function of $N$, then the lowest level of

\footnotetext{
${ }^{27}$ If $b<\underline{b}$, a moneylender could rely on only the present and future punishments he himself imposes on a borrower to deter default; social sanctions (through reputation effects) would not be necessary to sustain lending. The reason that we focus on the case $b>\underline{b}$ is that in this case, as reputation effects weaken, the moneylender's enforcement costs necessarily increase.

${ }^{28}$ Free rider problems create obstacles to the creation of credit bureaus; for an interesting analysis, see Klein (1992).
} 
enforcement effort for which an individual's best response is to repay has the properties

$$
e_{N}^{*}>0, e_{z_{0}}^{*} \geq 0, e_{i_{0}}^{*} \geq 0, e_{b}^{*}>0, e_{\beta}^{*}<0, e_{z_{0} N}^{*}=e_{i_{0} N}^{*}=0
$$

$e^{*}$ is increasing in all variables that increase the borrower's incentive to default: the number of moneylenders, principal and interest of the current loan, and the probability $(b)$ of exogenous separation. It is decreasing in the discount factor, since a higher discount factor means a higher utility weight on the future punishment from a default. The zero cross-derivatives reflect our simplifying assumption that the borrower's utility is separable in the intensity of enforcement effort and the terms of the current loan, and would not hold in a more general specification.

This section has illustrated how an increased number of moneylenders, by decreasing the probability that a default will be the common knowledge of all moneylenders, increases the enforcement costs of ensuring repayment from any borrower. As shown in the preceding section, in the presence of such enforcement externalities, a subsidy that induces new entry may cause the interest rate charged by moneylenders to rise.

\section{Conclusion}

This paper demonstrates two ways that a subsidy may increase equilibrium prices in a monopolistically competitive market. There may be induced entry and a resulting loss of scale economies, or induced entry with negative externalities in enforcement across suppliers.

Our central case of a market with strategic interaction among moneylenders illustrates the tension, brought about by new entry, between the extent of competition among moneylenders and the level of their enforcement costs. New entry into the moneylending activity reduces their market power, which tends to increase lending by each moneylender. But by weakening reputation effects, new entry raises the cost of enforcing loan repayment, which tends to reduce lending by each moneylender. Our surprising finding is that an increase in subsidized institutional credit to large landowners need not increase their on-lending to small landowners. Part of the increase in institutional credit to large landowners is dissipated through excessive entry into the moneylending activity, for example, expenditures on warehouses. The remainder may be "bottled up" among large landowners, including moneylenders, because the induced new entry has driven up the marginal enforcement cost of lending.

Our models are motivated by the striking similarities found in recent accounts of the role of traders as a source of informal rural credit. Key common findings are their methods of screening borrowers and enforcing repayment, their source of funds, and their ability to exercise market power despite low barriers to entry into 
the moneylending activity. By making us more skeptical about the trickle-down effects of subsidies to formal credit, our results provide support for the view that in order to increase poor households' access to capital, the formal sector must lend to them directly. This is the motivation of group lending programs, such as the Grameen Bank, which try to develop low-cost substitutes for the mechanisms used in the informal sector to screen borrowers and enforce repayment. Yet another way to address the limited access by the poor to credit are measures to improve infrastructure in poor villages, if such policies make it easier for banks or moneylenders to screen borrowers and obtain repayment. ${ }^{29}$

The paper provides a new illustration of the general principle that to correct a market failure it is necessary to know its source. While it seems natural to respond to an observed problem of high rural interest rates by increasing subsidized rural credit, if the source of the credit market failure is costly screening, resulting in market power, and endogenous enforcement costs, we have shown that this standard policy response can actually make the market failure worse.

\section{Acknowledgements}

We thank Larry Ausubel, Jean Lanjouw, and Peter Lanjouw for helpful discussions, and Tim Besley, Gabriel Fuentes, Ron McKinnon, and two referees for detailed comments. We also thank participants at the 1993 Meetings of the Econometric Society, and seminar participants at Baruch College, Boston University, Cornell, Maryland, Princeton, West Virginia, and Yale. This research was supported by the project for Institutional Reform and the Informal Sector (IRIS) at the University of Maryland (for Hoff) and the Institute for Policy Reform (for Stiglitz). The views expressed here are those of the authors and not necessarily those of the institutions with which they are, or have been, affiliated.

\section{Appendix A}

\section{A.1. Proof of propositions $1-3$}

Here we establish the local properties of the symmetric equilibrium of Model II. The symmetric equilibrium is determined by the first-order condition (12), the free entry condition (19), and the symmetry condition,

$$
i=\bar{i}=\hat{i}
$$

\footnotetext{
${ }^{29}$ See Binswanger et al. (1993) on the experience of India with bank lending, and our 1993 working paper for analysis of a simple case where subsidies to institutional credit are ineffective in improving the terms offered by moneylenders, but investments in infrastructure are effective.
} 
Substituting (A.1) into the first-order condition, the identity

$$
\psi(\hat{\imath}, \hat{\imath}, N, G)=0
$$

results. Substituting (A.1) into the free entry condition, the identity

$$
\Lambda(\hat{\imath}, N, G) \equiv v(\hat{\imath}, N, G)-H(G)=0
$$

results. We list below the six partial derivatives of $\psi$ and $\Lambda$ :

$$
\begin{aligned}
& \psi_{G}=-F^{\prime \prime}\left[m_{i} z+m z^{\prime}\right]<0 \\
& \psi_{\hat{\imath}}=\psi_{i}+\psi_{i}<0
\end{aligned}
$$

where the latter sign follows from (16);

$$
\begin{aligned}
\psi_{N}= & -\epsilon_{N} \frac{m}{i}\left[z\left[i-F^{\prime}\right]-e\right]-m_{i} e_{N}-m\left[e_{z N} z^{\prime}+e_{i N}\right] \\
& -F^{\prime \prime} \frac{L}{N}\left[m_{i} z+m z^{\prime}\right]
\end{aligned}
$$

identical to (17) and ambiguous in sign;

$$
\Lambda_{G}=F^{\prime}(K+G-\delta-m z)-F^{\prime}(K+G) \approx-[\delta+m z] F^{\prime \prime}>0
$$

where the approximation is a first-order Taylor expansion;

$$
\Lambda_{\hat{\imath}}=v_{\bar{i}}=m_{i}\left[z\left[i-F^{\prime}\right]-e\right]>0
$$

from (21); and

$$
\Lambda_{N}=v_{N}=-\frac{m}{N}\left[z\left[i-F^{\prime}\right]-e\right]-m e_{N}<0
$$

from (20).

Total differentiating (A.2) and (A.3) with respect to the policy variable, $G$, and writing these equations in matrix form, shows that

$$
\left[\begin{array}{ll}
\psi_{\hat{\imath}} & \psi_{N} \\
v_{\bar{\imath}} & v_{N}
\end{array}\right]\left[\begin{array}{l}
\frac{d \hat{\imath}}{d G} \\
\frac{d N}{d G}
\end{array}\right]=\left[\begin{array}{l}
-\psi_{G} \\
-\Lambda_{G}
\end{array}\right]
$$

Using Cramer's rule and rearranging using (22), the comparative statics relations $\mathrm{d} \hat{i} / \mathrm{d} G$ and $\mathrm{d} N / \mathrm{d} G$ are implicitly defined by

$$
\psi_{\hat{\imath}} V_{N} \frac{\mathrm{d} \hat{\imath}}{\mathrm{d} G}=-v_{N}\left\{\psi_{G}+\psi_{N}\left[\frac{\Lambda_{G}}{-v_{N}}\right]\right\}
$$

and

$$
-V_{N} \frac{\mathrm{d} N}{\mathrm{~d} G}=\Lambda_{G}+v_{\bar{i}}\left[\frac{\psi_{G}}{-\psi_{\hat{\imath}}}\right]
$$


Notice that the multiplier of $\mathrm{d} \hat{i} / \mathrm{d} G$ and that of $\mathrm{d} N / \mathrm{d} G$ are strictly positive (using (22)).

The proofs will refer to five distinct effects on which the comparative statics relations depend:

1. The differential effect of an increase in the subsidized credit ration, $G$, on the moneylender and on the large landowner who is not a moneylender, $\Lambda_{G} \approx$ $-F^{\prime \prime}[\delta+m z]>0$

2. Cost of capital effects, $-F^{\prime \prime} \frac{\partial(m z)}{\partial i}<0$ and $-F^{\prime \prime} \frac{\partial(m z)}{\partial N}<0$;

3. The enforcement cost effect of entry, $-m_{i} e_{N}-m\left[e_{z N} z^{\prime}+e_{i N}\right]$, which is ambiguous in sign;

4. The effect of entry on monopoly power, $\epsilon_{N}>0$; and

5. The strategic interaction effect among moneylenders $m_{i}>0$.

Proof of Proposition 1. The first term within the curly brackets of (A.4) is a direct cost of capital effect, $\psi_{G}=-F^{\prime \prime} \partial(m z) / \partial i<0$, which tends to reduce $\hat{i}$. The second term within the curly brackets of (A.4) has the same sign as $\psi_{N}$. The sign of $\psi_{N}$ depends on the relative magnitudes of three effects: an indirect cost of capital effect $\left(-F^{\prime \prime} \partial(m z) / \partial N\right)$, the enforcement cost effect, and the monopoly power effect of entry. If $\psi_{N}<0$, then the right-hand side of (A.4) is negative, which implies $\mathrm{d} \hat{i} / \mathrm{d} G<0$. See the lower part of Fig. 7 , where $\psi_{N}<0$ is reflected in the fact that the $\hat{i}(N, G)$ curve slopes down. In the alternative case, a positive enforcement cost effect dominates so that $\psi_{N}>0$. See Fig. 4(A,B), where $\hat{i}$ is increasing in $N$. The perverse result $\mathrm{d} \hat{i} / \mathrm{d} G>0$ obtains if the product of $\psi_{N}$ and $\partial N / \partial G=\Lambda_{G} /\left[-v_{N}\right]$ (which is always strictly positive) dominates the direct cost of capital effect:

$$
\psi_{N}\left[\frac{\Lambda_{G}}{-v_{N}}\right]>\left|\psi_{G}\right| \Rightarrow \frac{\mathrm{d} \hat{\imath}}{\mathrm{d} G}>0
$$

see Fig. 4(A).

Proof of Proposition 2. If there is no strategic interaction among moneylenders (i.e., $m_{\bar{i}}=0$ so $v_{\bar{i}}=0$ ), then each moneylender's profits are independent of the interest rates set by others. The only non-zero term in the right-hand side of (A.5) is $\Lambda_{G}$, the differential effect on the moneylender and on the large landowner who is not a moneylender. It follows from $\Lambda_{G}>0$ that $\mathrm{d} N / \mathrm{d} G>0$.

But with strategic interaction among moneylenders, we have $v_{i}>0$ and so $\left.v_{i} \psi_{G} /\left[-\psi_{i}\right]\right]<0$. (For given $i$ and $N, \bar{i}$ falls as $G$ expands, and the lower value of $i$ that other moneylenders choose lowers $v$.) If the latter effect is larger in absolute value than the differential effect, it follows from (A.5) that moneylenders exit as formal credit expands. See the upper part of Fig. 7, where the strategic interaction effect implies a smaller shift up in $V()$ than in $H()$ as $G$ expands. 
Proof of Proposition 3. Totally differentiating (A.3) shows that

$$
\Lambda_{G}+v_{i} \frac{\mathrm{d} \hat{\imath}}{\mathrm{d} G}=-v_{N} \frac{\mathrm{d} N}{\mathrm{~d} G}
$$

Since $\Lambda_{G}>0, v_{i}>0$, and $v_{N}<0$, exit implies $\mathrm{d} \hat{i} / \mathrm{d} G<0$.

\section{Appendix B}

Proof of proposition 5. Proposition 5 follows from two lemmas.

Lemma 1. Under the collectivist strategy at $\pi=0$, for $\beta$ sufficiently high and for any value of $b$, a moneylender is willing to lend to individuals who have not defaulted in the past.

Proof of Lemma 1. From the continuity argument in the text, there exists for any possible value of $b$ a unique value $\underline{\beta}(b)<1$ such that if $\beta>\beta(b)$, then moneylending to an individual with no history of default is profitable under the collectivist strategy. This is true for any possible value of $b$ and, in particular, for $b=1$. But if moneylending is profitable at $\beta>\beta(1)$ and $b=1$, then it is also profitable at $\beta>\beta(1)$ and $b<1$, since a fall in $b$ lowers $e^{*}$, which increases the moneylender's gain from lending.

Lemma 2. Under the collectivist strategy at $\pi=0$, for any value of $\beta$ and for $b$ sufficiently high, a moneylender is unwilling to lend to individuals who have defaulted in the past.

Proof of Lemma 2. Under the collectivist strategy, the future lifetime expected utility of an individual who has defaulted in the past, who is currently attached to a moneylender, and who will repay in the future, is

$$
\tilde{W}^{r} \equiv u^{r}+\beta[1-b] \tilde{W}^{r}
$$

Notice that $\tilde{W}^{r}$ is only the utility the individual obtains from transactions with his current moneylender, since he does not expect any other moneylender to be willing to lend to him.

The borrower's best response is to repay if

$$
\tilde{W}^{r} \geq u^{d}-e+\left.W^{d}\right|_{\pi=0}=u^{d}-e
$$

Substituting and rearranging yields the enforcement effort necessary to induce repayment from a borrower with a bad credit history:

$$
e \geq u^{d}-u^{r}-\beta u^{r}\left[\frac{1-b}{1-\beta[1-b]}\right] \equiv e^{* *}
$$


The payoff to lending at terms $(z, i)$ to an individual with a bad credit history is

$$
\begin{gathered}
z\left[i-F^{\prime}\right]-e^{* *} \\
=z\left[i-F^{\prime}\right]-\left[u^{d}-u^{r}\right]+\beta u^{r}\left[\frac{1-b}{1-\beta[1-b]}\right]
\end{gathered}
$$

(A.6) is monotonically decreasing in $b .(24 \mathrm{~b})$ states that $z\left[i-F^{\prime}\right]-u^{d}-u^{r}<$ 0 . It follows immediately that at $b=1$ (i.e., no moneylender continues in the market for more than one period), (A.6) is negative. At $b=0$ (i.e., no moneylender ever leaves the market), $e^{* *}=\left.e^{*}\right|_{\pi=0}$, and the moneylender's payoff is strictly positive. By continuity, $b$ exists. $b$ is implicitly defined by setting (A.6) equal to zero. $b>\underline{b}$ implies $\bar{e}^{* *}$ so high that the moneylender's payoff is negative. But for $e$ set below $e^{* *}$, say at $e^{*}$ in (25), a borrower with a bad credit history would not repay. Collectivist beliefs are thus self-fulfilling.

\section{References}

Aleem, I., 1990, Imperfect information, screening and the costs of informal lending: A study of rural credit markets in Pakistan, World Bank Economic Review 4, 329-349.

Austin, G., 1993, Indigenous credit institutions in West Africa, c.1750-c.1960, in: G. Austin and K. Sugihara, eds., Local Suppliers of Credit in the Third World, 1750-1960 (St. Martin's Press, New York)

Basu, K., 1994, Rural credit and interlinkage: Implications for rural poverty, agrarian efficiency, and public policy, DEP Working Paper No. 54, London School of Economics.

Bell, C., 1990, Interactions between institutional and informal credit agencies in rural India. World Bank Economic Review 4, 297-327.

Bhaduri, A., 1987, Moneylenders, pp. 526-527 in: J. Eatwell, M. Milgate and P. Newman, eds., The New Palgrave, A Dictionary of Economics (Macmillan, London).

Binswanger, H.P., S.R. Khandker and M.R. Rosenzweig, 1993, How infrastructure and financial institutions affect agricultural output and investment in India, Journal of Development Economics $41,337-366$.

Bolnick, B., 1992, Moneylenders and informal financial markets in Malawi, World Development 20. 57-68.

Bose, P., 1994, Formal-informal sector interaction in rural credit markets, State University of New York at Cortland, mimeo.

Conning, J., 1994, Linked contracts as collateral substitutes: Theory and some evidence from the market for farm finance in Chile, Ph.D. thesis, Yale University.

de Meza, D. and J.R. Gould, 1992, The social efficiency of private decisions to enforce property rights, Journal of Political Economy, 100, 561-580.

de Meza, D., J. Maloney and G. Myles, 1995, Price-reducing taxation, Economics Letters 47, 77-81.

Diamond, P., 1971, A model of price adjustment, Journal of Economic Theory 3, 156-168.

Floro, S. and D. Ray, 1997, Vertical links between formal and informal financial institutions: An analytical approach, Review of Development Economics, forthcoming.

Floro, S. and P. Yotopoulos, 1991, Informal Credit Markets and the New Institutional Economics: The Case of Philippine Agriculture (Westview Press, Boulder, CO).

Greif, A., 1994, Cultural beliefs and the organization of society: A historical and theoretical reflection on collectivist and individualist societies, Journal of Political Economy 102, 912-950. 
Hoff, K. and J.E. Stiglitz, 1993a, Imperfect information and rural credit markets: Puzzles and policy perspectives, pp. 33-52 in: K. Hoff, A. Braverman and J.E. Stiglitz, eds., The Economics of Rural Organization: Theory, Practice, and Policy (Oxford University Press, New York).

Hoff, K. and J.E. Stiglitz, 1993b, A theory of imperfect competition in rural credit markets in developing countries, University of Maryland, IRIS working paper \#78.

Horstmann, I.J. and J.M. Markusen, 1986, Up the average cost curve: Inefficient entry and the new protectionism, Journal of International Economics 20, 225-247.

Jain, S., 1995, The interaction of formal and informal credit markets in developing countries: Symbiosis versus crowding out, mimeo.

Klein, D.B., 1992, Promise keeping in the great society: A model of credit information sharing, Economics and Politics 4, 117-136.

Klein, B. and K.B. Leffler, 1981, The role of market forces in assuring contractual performance, Journal of Political Economy 89, 615-641.

Lipton, M., 1976, Agricultural finance and rural credit in poor countries, World Development 4, $543-553$.

Lipton, M. and J. Toye, 1989, Does Aid Work in India? (Routledge, London).

Nagarajan, G., 1992, Informal credit markets in Philippine rice-growing areas, Ph.D. thesis, Ohio State University.

Onchan, T., 1992, Informal rural finance in Thailand, in: D. Adams and D.A. Fitchett, eds., Informal Finance in Low-Income Countries (Westview Press, Boulder, CO).

Satterthwaite, M., 1979, Consumer information, equilibrium industry price, and the number of sellers, Bell Journal of Economics 10, 483-502.

Shapiro, C. and J.E. Stiglitz, 1984, Equilibrium unemployment as a worker discipline device, American Economic Review 74, 433-444.

Sharma, P., 1985, Borrowing costs, debt capacity and demand for agricultural finance in Fiji, Savings and Development 9, 459-467.

Siamwalla, A., C. Pinthong, N. Poapongsakorn, P. Satsanguan, P. Nettayarak, W. Mingmaneenakin and Y. Tubpun, 1990, The Thai rural credit system: Public subsidies, private information, and segmented markets, World Bank Economic Review 4, 271-296.

Stiglitz, J.E. and A. Weiss, 1981, Credit rationing in markets with imperfect information, American Economic Review 71, 383-410.

Walker, T.S. and Ryan, J.G., 1990, Village and Household Economies in India's Semi-Arid Tropics (Johns Hopkins University Press, Baltimore).

Williamson, S., 1987, Costly monitoring, loan contracts, and equilibrium credit rationing, Quarterly Journal of Economics 102, 135-146. 